\title{
Testing Nanomaterial Toxicity in Unicellular Eukaryotic Algae and Fish Cell Lines
}

\author{
Alexandra Kroll, Dana Kühnel, and Kristin Schirmer
}

\begin{abstract}
Nanoecotoxicology as a sub-discipline of ecotoxicology aims to identify and predict effects elicited on ecosystems by nano-sized materials (NM). Two key groups of model organisms in this context are algae and fish. In this chapter, we present considerations for testing NM with respect to their impact on unicellular algae and cell lines derived from various organs of fish.

Based on currently available literature on NM effects in unicellular algae and fish cell lines, and our own experience, we provide guidance on test design, including principle test considerations, materials, NM presentation to cells, exposure, bioavailability, and effect assessment. Assessment needs to be based on a meaningful choice of exposure scenario(s) related to the research question. As a first step, one needs to address whether effects of NMs are to be investigated under environmentally relevant or probable conditions, which may include processes such as agglomeration, or whether NM effects from mono-dispersed particles are of interest, which may require special steps to ensure stable NM suspension. Moreover, whether effects on cells are to be studied in the short- or long-term is important with regard to experimental design. Preparation of NM suspensions, which can be done in aqueous media different from the exposure medium, is addressed with regard to energy input, sterility (as required for algae and fish cell exposure) and particle purity.

Specified for the two model systems, algae and fish cell lines, availability and choice of culture media are presented and discussed with regard to impact on NM behavior. Light, temperature, and agitation, which are variables during exposure, are discussed. We further provide guidance on the characterization of the NM in the chosen aqueous exposure media regarding size, zeta potential and electrophoretic mobility. The state of NM in exposure media is decisive for their bioavailability and therefore for potential particle effects. Therefore, we present ways of deriving a mass balance and quantitative/qualitative information on the uptake and distribution of NM in cells.

As NM have a high surface-to-volume ratio and possess specific physical-chemical properties, which make them prone to interfere with various compounds and certain types of toxicity tests, potential interferences and appropriate controls are introduced. Furthermore, different types of dose metrics, which is still a strongly debated issue in nanotoxicology, are highlighted. We also consider laboratory safety regarding NM handling and disposal.
\end{abstract}

Key words Ecotoxicology, Algae, Fish cells, Nanomaterial properties, Nanoparticle characterization, Test design, Exposure scenario, Toxicity, Uptake, Accumulation 


\section{Introduction}

Nanoecotoxicology has recently emerged as a subdiscipline of ecotoxicology and aims to identify and predict effects elicited on ecosystems by nano-sized materials. According to a recent definition by the EU, "nanomaterial" (NM) means a natural, incidental, or manufactured material containing particles in an unbound state or as an aggregate or as an agglomerate and where, for $50 \%$ or more of the particles in the number size distribution, one or more external dimensions is in the size range $1-100 \mathrm{~nm}[1]$. In the following, we refer to spherical NM as nanoparticles (NP). Agglomerates of NM are based on weak interactions, whereas chemical bonds between NM are formed in aggregates [2]. To achieve its aims, nanoecotoxicology needs to take into consideration the entry routes and fate of NM in the abiotic and biotic environment to define exposure. It moreover needs to identify those interactions of NM with biota that alter the proper function of cells comprising an organism, thus impacting populations, which in turn can lead to changes in community structure and function. For nanoecotoxicology concerned with the aquatic environment, key species of consideration are algae and fish. Algae are important primary producers in aquatic ecosystems and represent the group of photoautotrophic organisms. In contrast, fish are heterotrophs further up the food chain; with many conserved functions in vertebrates, they are also considered early indicators of impacts on water quality on higher vertebrates, including humans.

In this chapter, we present key considerations for testing NM with respect to their impact on algae and fish using cellular models, specifically, unicellular algae and cell lines derived from various organs of fish. Currently, algae are a paraphyletic group of eukaryotes that conduct photosynthesis in chloroplasts and that differ from plants in, a.o., reproduction and anatomy (e.g., ref. 3). They fall into different groups according to the origin and architecture of their chloroplasts including pigmentation. Cyanobacteria are not included in this definition. Here we focus on unicellular algae as opposed to colonial or filamentous algae. A selection of unicellular algae has become widely used model organisms. Algae form the base of the food web in aquatic ecosystems. In toxicity tests, algal species often prove to be more sensitive than other model organisms [4]. Algae can be isolated from their natural habitat and cultured at standardized conditions in the laboratory [5]. The challenge is to generate cultures of a single species that is not contaminated by bacteria or fungi (axenic). Some algae species cannot be kept axenically as they depend on symbiotic bacteria (e.g., in Rhopalodia gibba, a diatom [6]). If the culture conditions are appropriate, algae can be cultured indefinitely. Fish cell lines can be 
derived from primary cultures of cells, tissues, or organs taken directly from organisms. If a primary culture can be divided into new culture vessels and successfully propagated, it becomes a cell line. A cell line may be propagated a limited number of times, in which case it is finite or, indefinitely, in which case it becomes an immortal or continuous (or permanent) fish cell line [7, 8]. Cell lines from a variety of different species of fish and from different tissues and organs have been established in this way. In contrast to mammalian cells, many fish cell lines arise spontaneously without any specific immortalization treatment, possibly owing to a high telomerase activity [7]. A wide range of both unicellular algae and fish cell lines are commercially available through dedicated repositories, such as the Culture Collection of Algae and Protozoa (CCAP $[9,10])$ and the American Type Culture Collection for fish cell lines (ATCC, e.g., refs. $[7,11]$ ), or they can be obtained from other research laboratories.

Owing to their small size and ease to produce them in rather large numbers, unicellular algae and fish cells are very useful to study a variety of NM in small-scale assays on integrative parameters, such as cell survival and reproduction, but as well on mechanisms of NM uptake and toxicity. Small scale refers to small flasks, holding a few milliliters of medium, down to multi-well plates with micro- to nanoliter volumes of exposure medium, making these tests amenable not only to high throughput screening but also to reduced material resources and, consequently, reduced waste. However, the small scale also bears problems, such as the high surface-to-volume ratio of test containers or little material for characterizing NM as they are present in the exposure chambers.

A summary of currently available publications on NM effect studies using unicellular algae and fish cell lines is presented in Tables 2 and 3. Based on these studies, and taking our own experience into consideration, we would like to provide guidance on test design in terms of principle test considerations, NM presentation to cells, exposure, bioavailability, and effect assessment.

\section{Materials}

Materials specifically recommended for working with NM in algae or fish cell culture environments are as follows:

\subsection{Equipment}

1. High-precision, antistatic scale to weigh NM provided as powder.

2. Ultrasonic bath or sonication cup to fit on a sonication tip for indirect sonication of NM dispersions (direct sonication may add impurities to your sample!). 


\section{Table 1}

\section{Possible interferences of NM with cell-based toxicity tests and adequate controls}

\begin{tabular}{|c|c|}
\hline Interference & Control \\
\hline $\begin{array}{l}\text { Quenching of fluorescence emitted from test } \\
\text { reaction product }\end{array}$ & $\begin{array}{l}\text { Measure known concentrations of NM and } \\
\text { reaction product in combination }\end{array}$ \\
\hline $\begin{array}{l}\text { Quenching of fluorescence emitted from } \\
\text { organism (e.g., algal autofluorescence) }\end{array}$ & $\begin{array}{l}\text { Difficult to control as change in fluorescence } \\
\text { is the end point; wash organisms to } \pm \\
\text { remove NM }\end{array}$ \\
\hline $\begin{array}{l}\text { Light absorption at the wavelength used in a } \\
\text { fluorescence or light absorbance measurement }\end{array}$ & $\begin{array}{l}\text { Measure light absorption spectrum of NM at } \\
\text { known concentrations }\end{array}$ \\
\hline $\begin{array}{l}\text { Autofluorescence (in the respective wavelength } \\
\text { required for detection in the assay) }\end{array}$ & Measure fluorescence of NM suspension \\
\hline $\begin{array}{l}\text { Conversion of assay substrates, e.g., by catalysis } \\
\text { or ROS formation }\end{array}$ & $\begin{array}{l}\text { Incubate NM with assays substrates and } \\
\text { measure end point taking into account } \\
\text { possible optical interference and sorption } \\
\text { (see above) }\end{array}$ \\
\hline Binding of assay compounds & $\begin{array}{l}\text { Difficult to control (separate them from cells } \\
\text { and prevent necessary interactions) }\end{array}$ \\
\hline $\begin{array}{l}\text { Interference with an enzyme (inhibition, } \\
\text { enhancement) and/or adsorption of assay } \\
\text { substrates or products }\end{array}$ & $\begin{array}{l}\text { Incubate known concentrations of enzyme, } \\
\text { substrate, and NM and measure end point, } \\
\text { taking into account possible optical } \\
\text { interference and sorption (see above) }\end{array}$ \\
\hline Interaction with RNA/DNA, PCR mixes & $\begin{array}{l}\text { Treat known concentrations of RNA/DNA } \\
\text { with NM dispersions and perform PCRs in } \\
\text { the presence of NM to check for } \\
\text { interference/destruction }\end{array}$ \\
\hline Shading & Use external shading \\
\hline $\begin{array}{l}\mathrm{pH} \text { is influenced by NM-e.g., change in } \\
\text { fluorescence of fluorophores }\end{array}$ & Check $\mathrm{pH}$ in the presence of $\mathrm{NM}$ \\
\hline $\begin{array}{l}\text { Nutrient or growth factor depuration } \\
\text { (NM adsorb compounds from the media) }\end{array}$ & Analyze compounds associated with NM \\
\hline
\end{tabular}

3. Stir plates with exact (digital) displays for reproducible stirring of NM dispersions.

4. Room or incubator with controlled light and temperature conditions for the generation of dispersions and exposure of test organisms.

\subsection{Reagents and Supplies}

Please refer to specific literature on NM characterization (e.g., ref. 12) and on algae (e.g., ref. 5) and fish cell culture (e.g., ref. 13, 14), as well as the small-scale assays cited in Tables 1 and 2 , for details on specific infrastructure, instruments, consumables, and chemicals. Be sure to protect yourself and your colleagues from exposure to NM (see Note 1). 


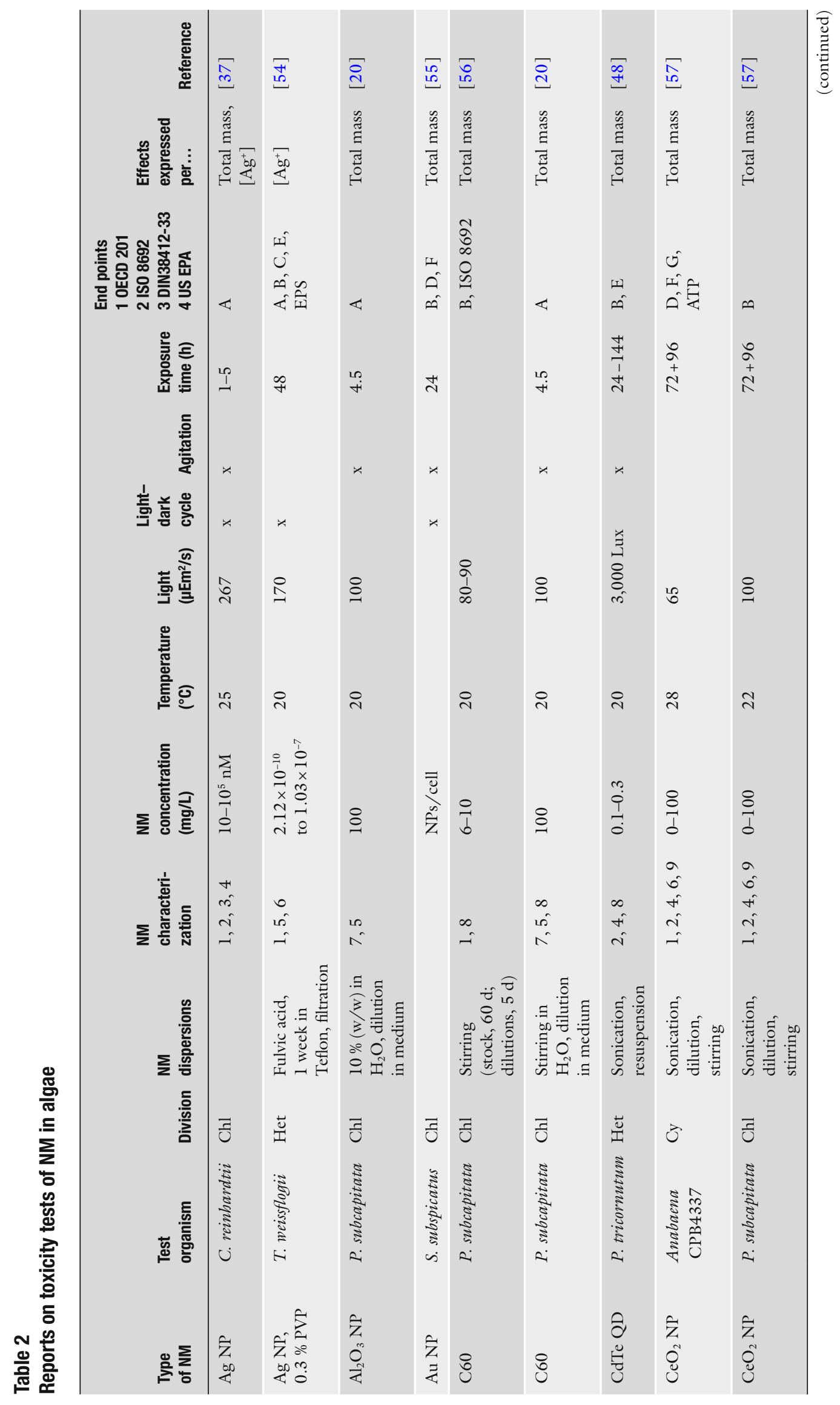




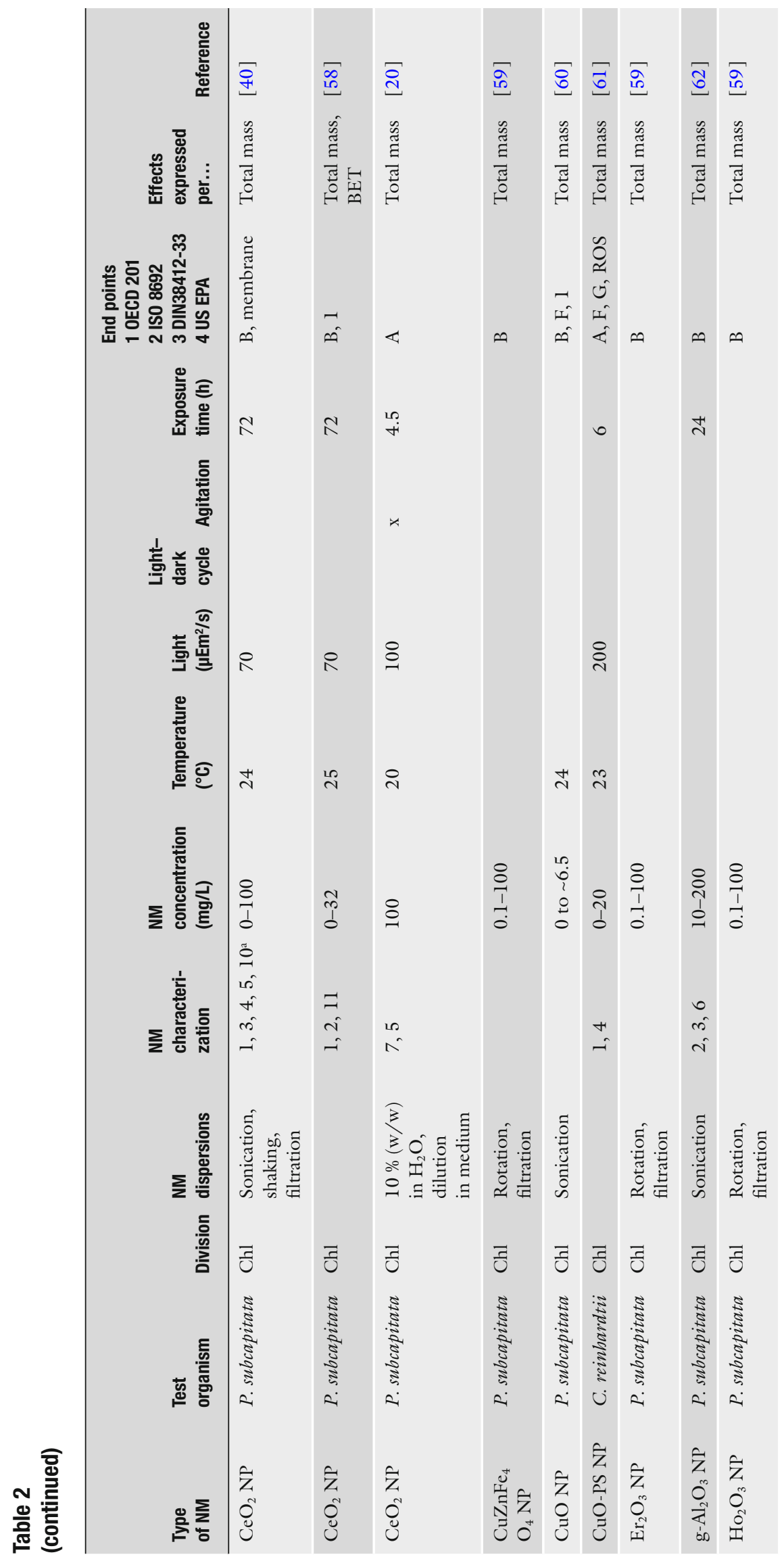




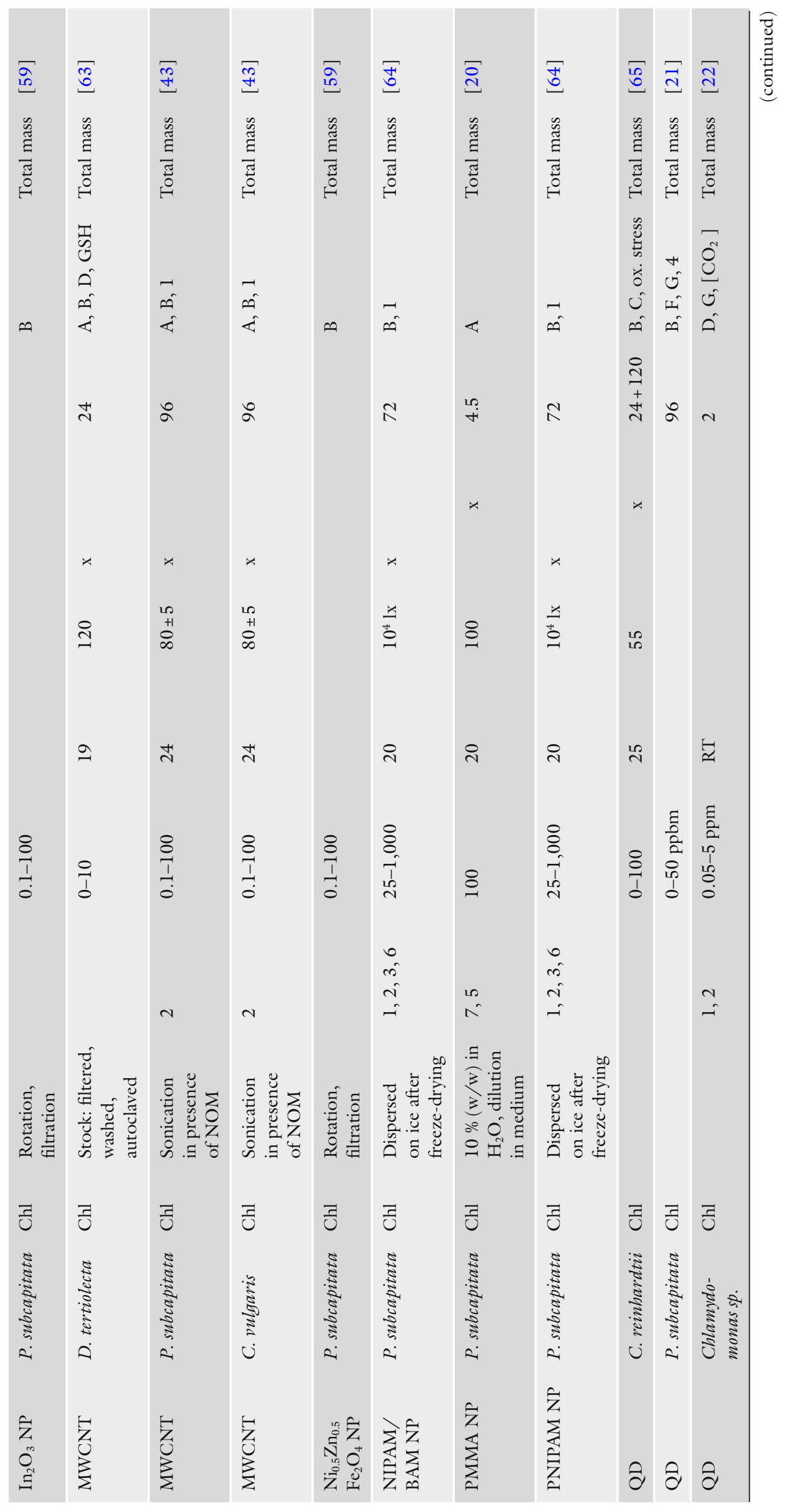




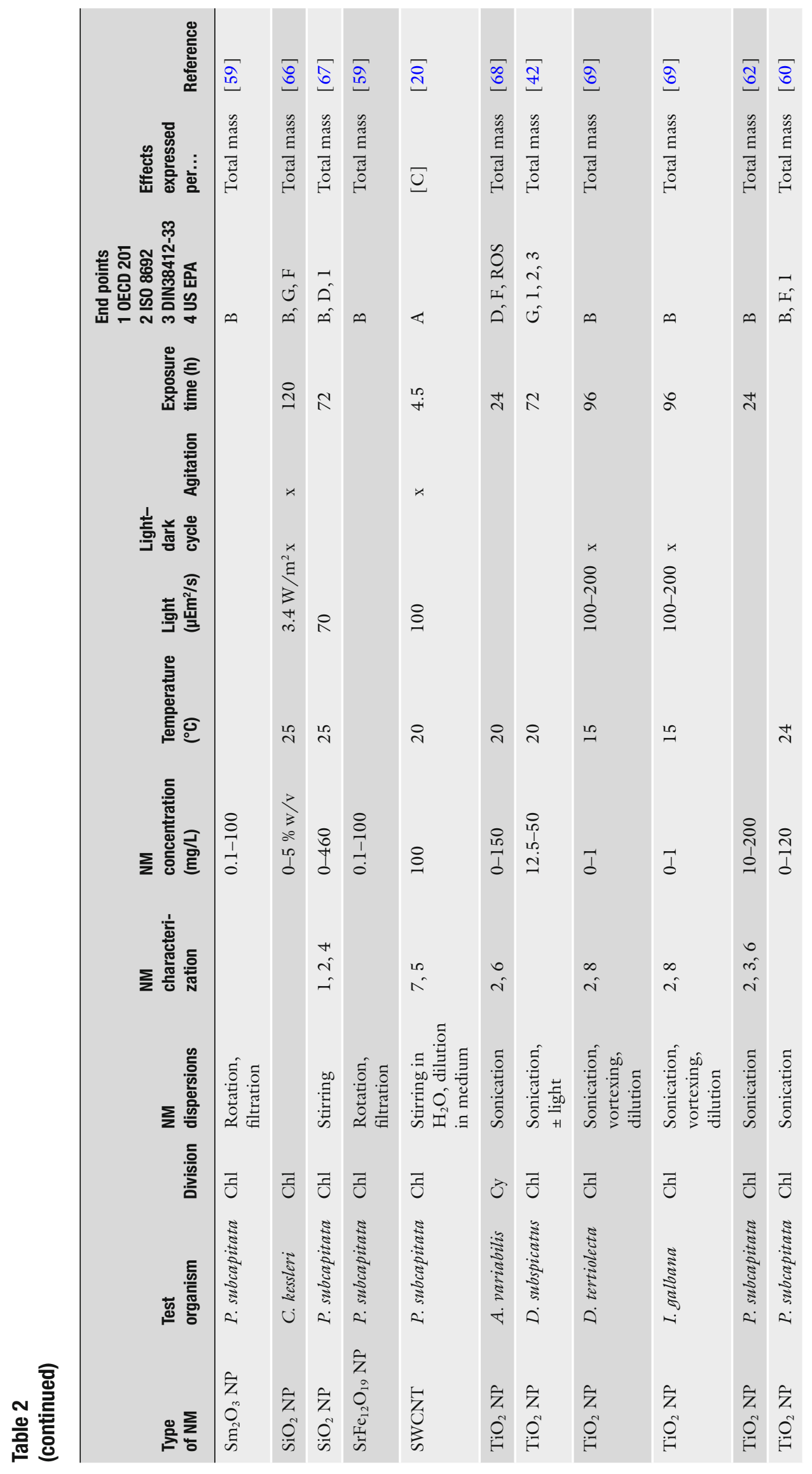




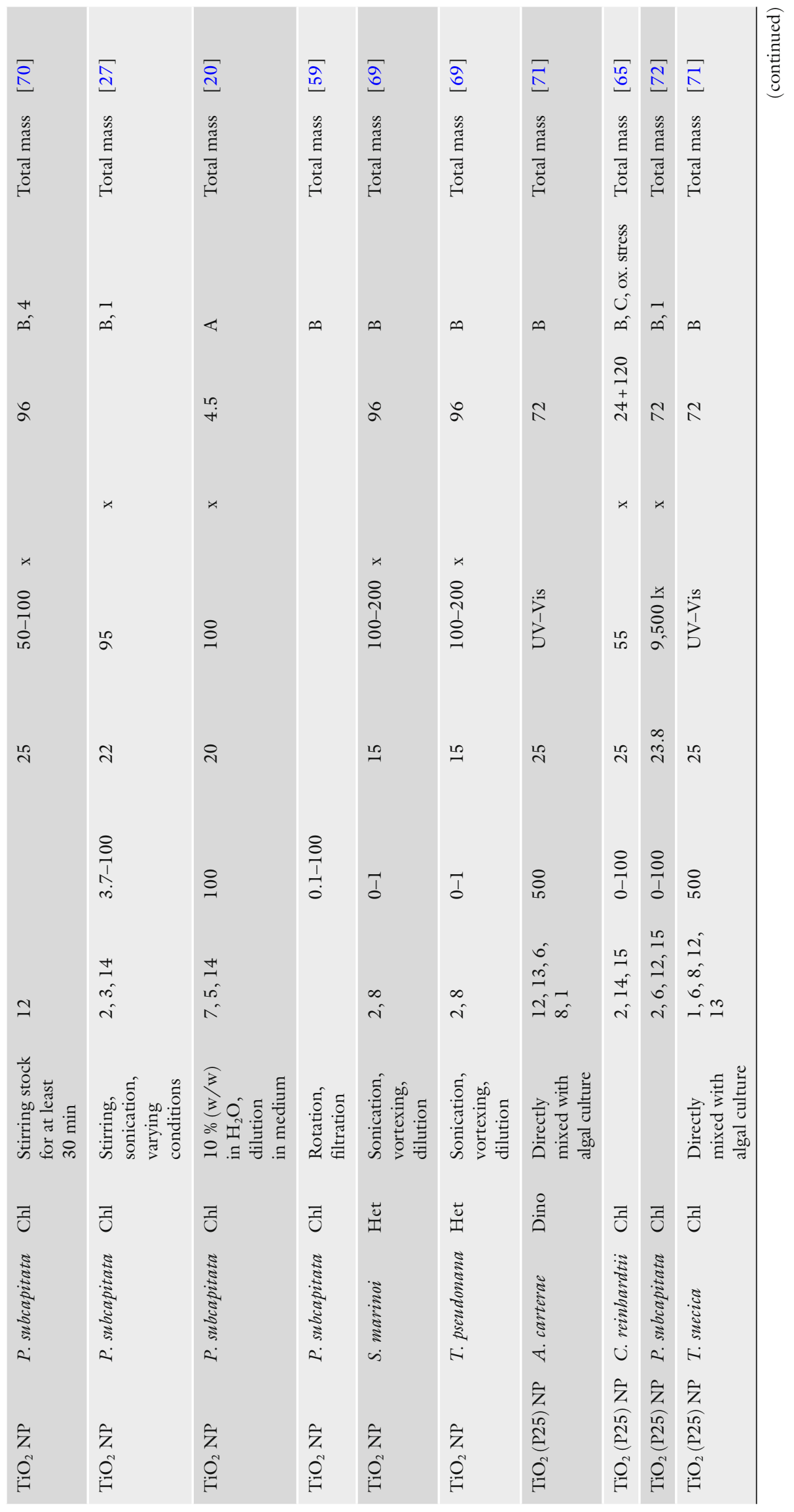




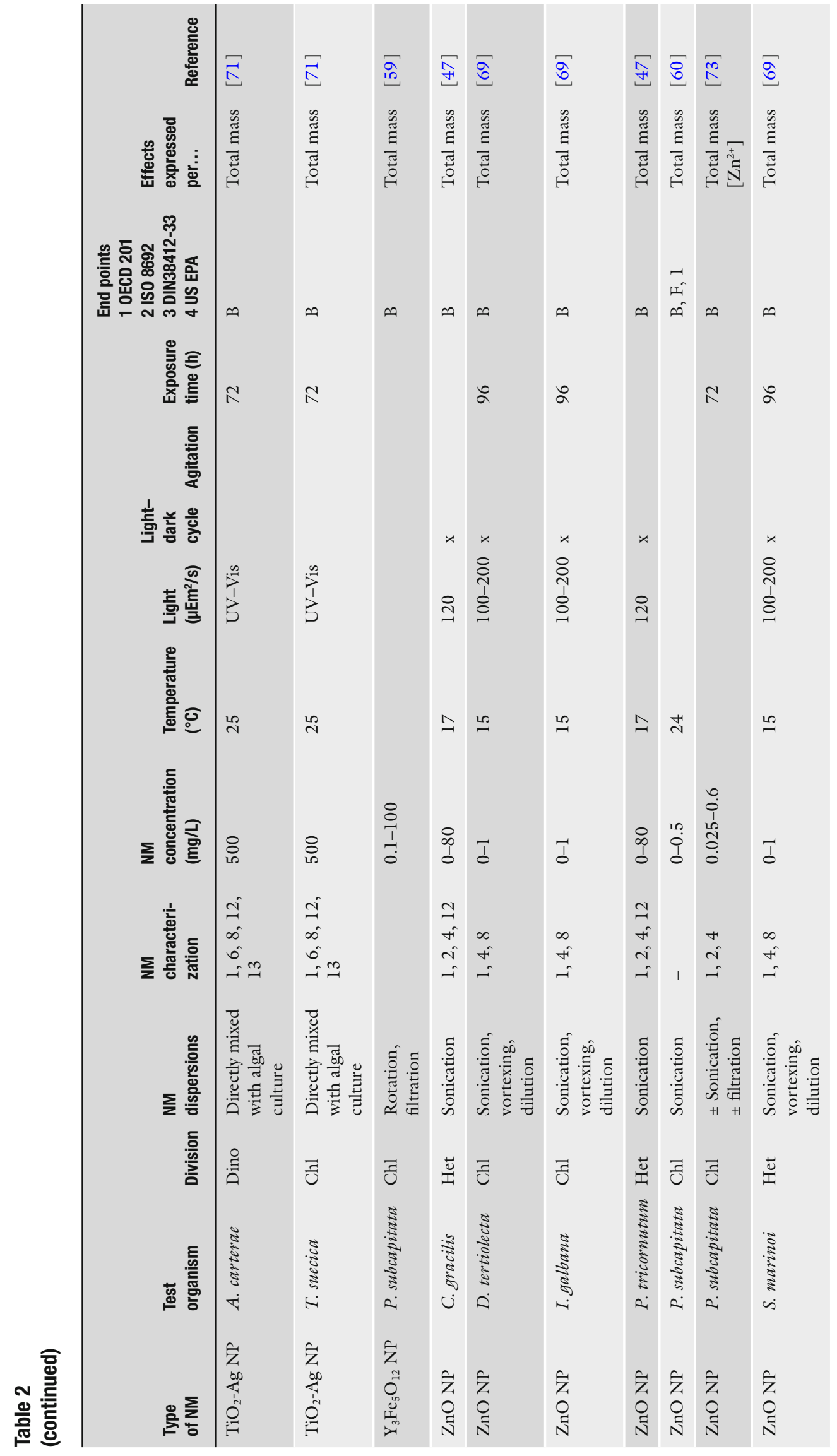




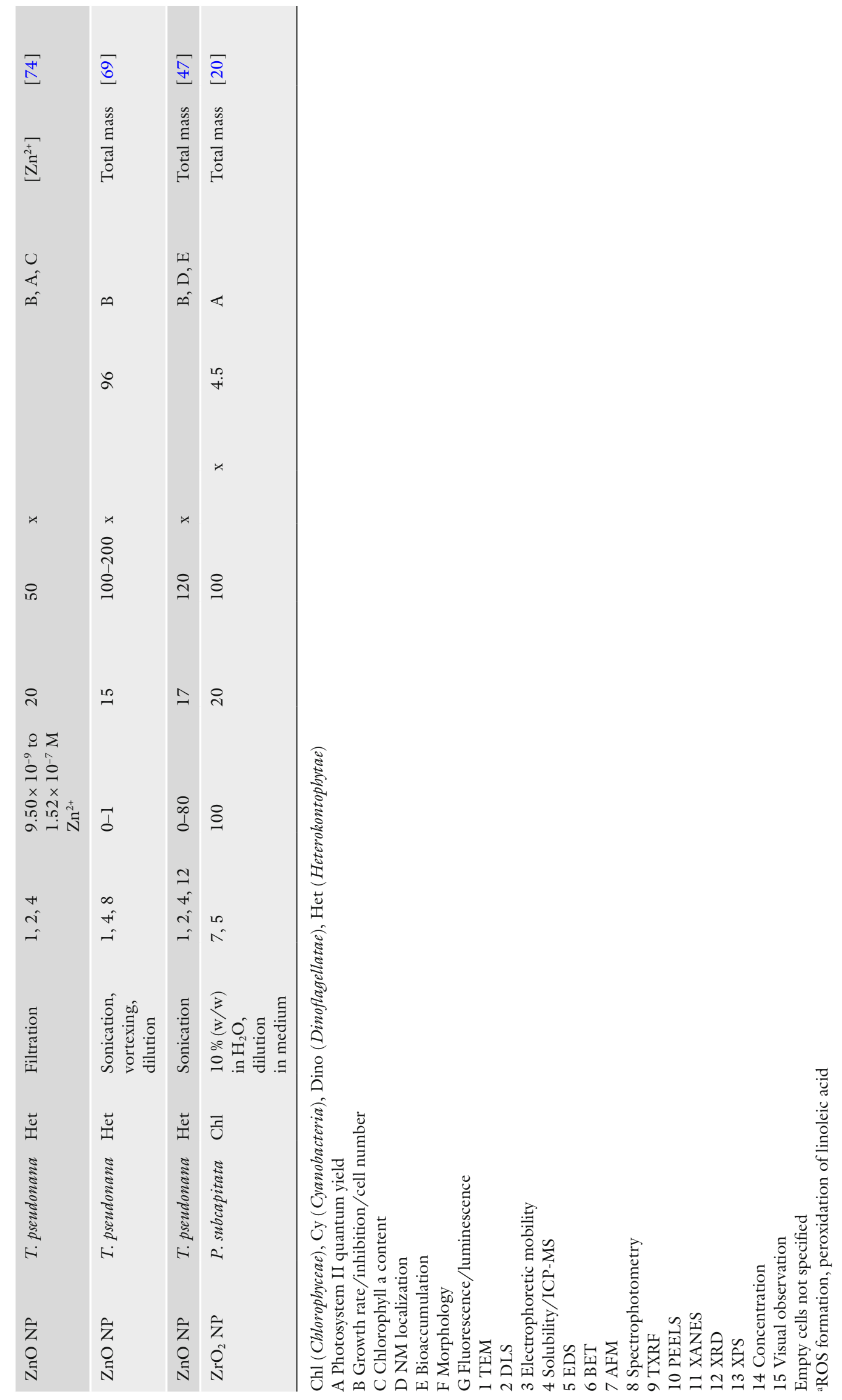




\section{Methods}

\subsection{Considerations for Selection of Cells}

3.1.1 Unicellular

Eukaryotic Algae
This chapter guides through important elements in designing experiments to assess the toxicity of NMs in unicellular algae and fish cell lines. Inasmuch as the dominant route of exposure to NMs toward these organisms in the aquatic environment is via NM dispersions (aside from uptake in fish through food), we will focus this chapter on exposure via liquid media and NMs dispersed into it. A general design scheme is presented in Fig. 1. This scheme assumes a prior selection of cells. This selection needs to be decided upon according to the question at hand, availability of desired cell types, and other potential considerations as briefly summarized below.

The three NM-specific considerations are the algal cell wall, algal class, and habitat. Algal cell walls are composed of silica in diatoms and of polysaccharides and/or glycoproteins in other groups. Consequently algal cell walls have different chemical and physical properties that will possibly influence the availability of NM at the cell membrane. The silica-based cell wall or frustule of diatoms has pores and slits of defined sizes which filter material from the surrounding medium. A study on two diatom species revealed a lower size limit of $40 \mathrm{~nm}$ in frustule pores, possibly limiting the diffusion of larger particles to the cell membrane [15]. Other classes may have additional routes of uptake for NM, such as dinoflagellates

\begin{tabular}{|c|c|c|c|c|c|}
\hline \multirow{2}{*}{$\begin{array}{c}\text { Principle } \\
\text { considerations }\end{array}$} & \multicolumn{3}{|c|}{$\begin{array}{l}\text { Effects of NM under } \\
\text { environmentally } \\
\text { relevant/probable conditions }\end{array}$} & \multicolumn{2}{|c|}{$\begin{array}{l}\text { Effects of NM under worst-case } \\
\text { conditions }\end{array}$} \\
\hline & $\begin{array}{l}\text { Short-term } \\
\text { exposure }\end{array}$ & $\begin{array}{l}\text { Lon } \\
\text { exp }\end{array}$ & & $\begin{array}{l}\text { Short-term } \\
\text { exposure }\end{array}$ & $\begin{array}{l}\text { Long-term } \\
\text { exposure }\end{array}$ \\
\hline $\begin{array}{l}\text { Nanomaterial } \\
\text { presentation }\end{array}$ & \multicolumn{3}{|c|}{$\begin{array}{c}\text { Environmentally } \\
\text { relevant/probable dispersions } \\
\text { (possibly agglomeration of NM) }\end{array}$} & \multicolumn{2}{|c|}{$\begin{array}{l}\text { Stable, monodisperse NM } \\
\text { with narrow size distribution }\end{array}$} \\
\hline Exposure & \multicolumn{3}{|c|}{$\begin{array}{l}\text { Environmentally } \\
\text { relevant/probable conditions } \\
\text { (e.g. aqueous media, } \\
\text { temperature, radiation); } \\
\text { specific requirements of cells during } \\
\text { short-term vs. long-term exposure? }\end{array}$} & \multicolumn{2}{|c|}{$\begin{array}{l}\text { Optimized for stable NM } \\
\text { dispersions (e.g. modified } \\
\text { exposure media); } \\
\text { specific requirements of cells during } \\
\text { short-term vs. long-term exposure? }\end{array}$} \\
\hline Bioavailability & \multicolumn{2}{|c|}{ NM quantity and quality } & & $\begin{array}{l}\text { xposure medi } \\
\text { ociated with o }\end{array}$ & in cells \\
\hline Effects & \multicolumn{5}{|c|}{$\begin{array}{l}\text { - appropriate controls; consideration of potential interferences } \\
\text { - dose metrics }\end{array}$} \\
\hline
\end{tabular}

Fig. 1 Scheme for the design of toxicity tests of nanomaterials 


\subsubsection{Fish Cell Lines}

\subsection{Principle Considerations for Test Design}

that can ingest food particles (e.g., ref. 16). The original habitat and thus the required medium will influence the fate of NM during exposure. Marine algae, for example, require high salt medium as opposed to freshwater algae. The ionic strength strongly influences the stability of NM dispersions.

Fish cell lines are not as diverse in structure as algae cells, but the species and its associated habitat and the organ or tissue of origin are likewise important considerations. Inasmuch as fish cell lines generally thrive in temperatures closely mimicking the environment of their donor, cells from warm and cold water fish have very different temperature requirements. For example, cell lines from rainbow trout (Oncorhynchus mykiss) can be cultured between 4 and $25{ }^{\circ} \mathrm{C}$, whereas cell lines from warm water fish, such as from zebra fish (Danio revio), grow at temperatures also above $25{ }^{\circ} \mathrm{C}$ $\left(23-34{ }^{\circ} \mathrm{C}\right)$. The organ or tissue of origin is important for consideration of specific target sites. For example, if one wants to mimic the exposure scenario at the gill, exposure media closely mimicking the fresh- or saltwater environment may be applied [11]. Moreover, in analogy to dinoflagellates, macrophage cells have additional routes of NM uptake, i.e., phagocytic routes, not of such relevance to other cell types.

The assessment of NM toxicity needs to be based on a meaningful choice of exposure scenario(s) related to the research questions. The two possible "extreme" cases are sketched in Fig. 1. If the research focus is on the effects of NM under environmentally relevant or probable conditions, the use of natural water chemistry and low NM concentrations is implied. Due to the lack of measured data, different authors have estimated or modeled NM concentrations (such as $\mathrm{TiO}_{2^{-}}, \mathrm{CeO}_{2^{-}}, \mathrm{Ag}$-based nanoparticles (NP)) which average in the ng/L range and below in surface waters, meaning several orders of magnitude below most reported test concentrations (Tables 2 and 3) [17-19]. To investigate NM effects in a "worst-case" exposure scenario, establishing a doseresponse curve is necessary. However, the use of high NM concentrations may be limited by interference with toxicity assays (see Subheading 3.6.1), whereas low concentrations of NM are difficult to quantify and characterize (see Subheading 3.5).

Furthermore, the exposure duration needs to be considered (Fig. 1). In the literature, exposure is typically grouped in shortterm (hours to days) and long-term (days to weeks) approaches. As the life cycle of NM in the environment has not been studied yet, we do not have any data to base our selection on. From other anthropogenic inputs into surface waters, we know that there may be pulsed and long-term/chronic exposure. Both may thus apply to NM, too. Reported exposure times in nanotoxicity studies range from $4.5 \mathrm{~h} \mathrm{[20]} \mathrm{to} 5 \mathrm{~d}$ [21] in algae and from 3 to $72 \mathrm{~h} \mathrm{[22]}$ 


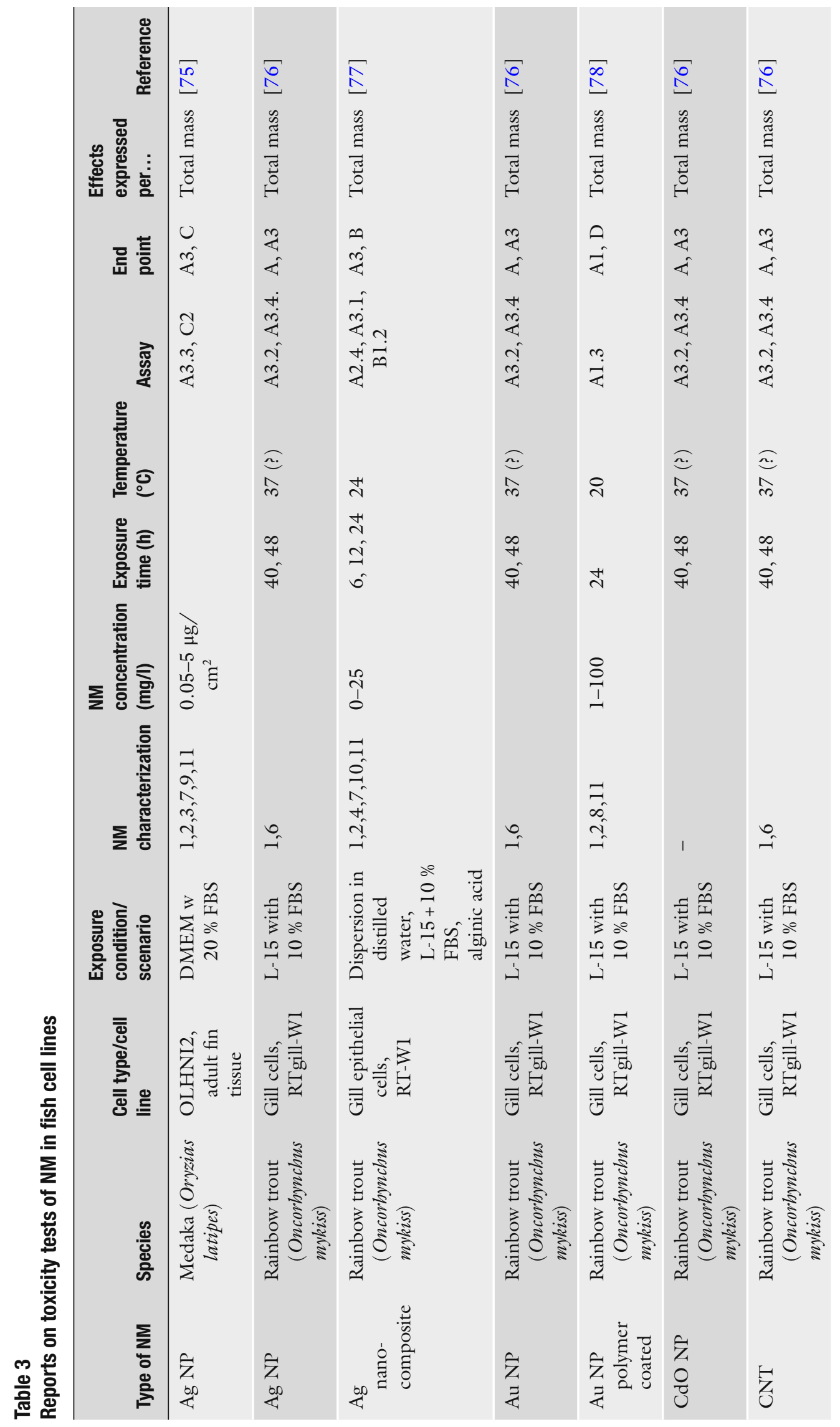




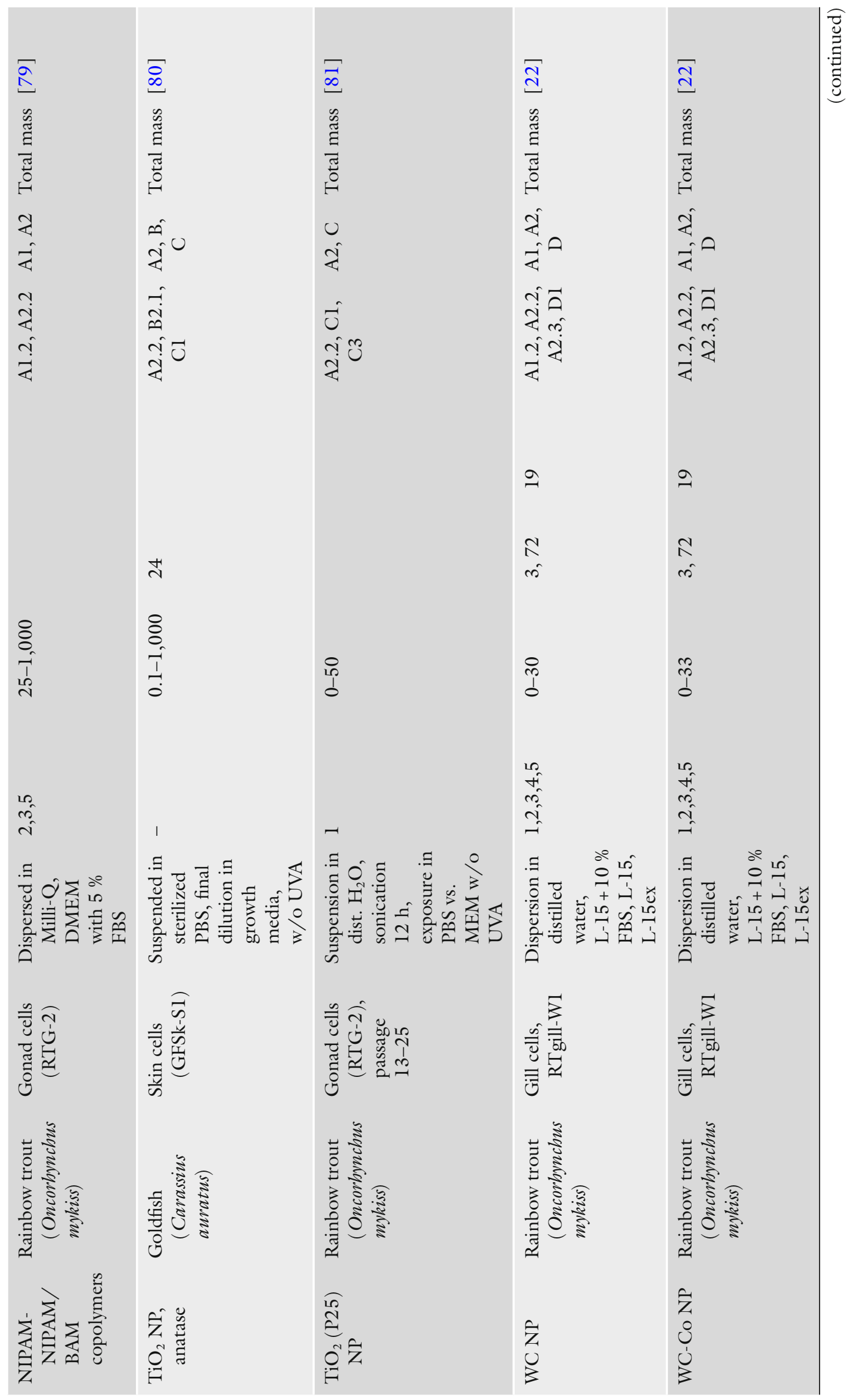




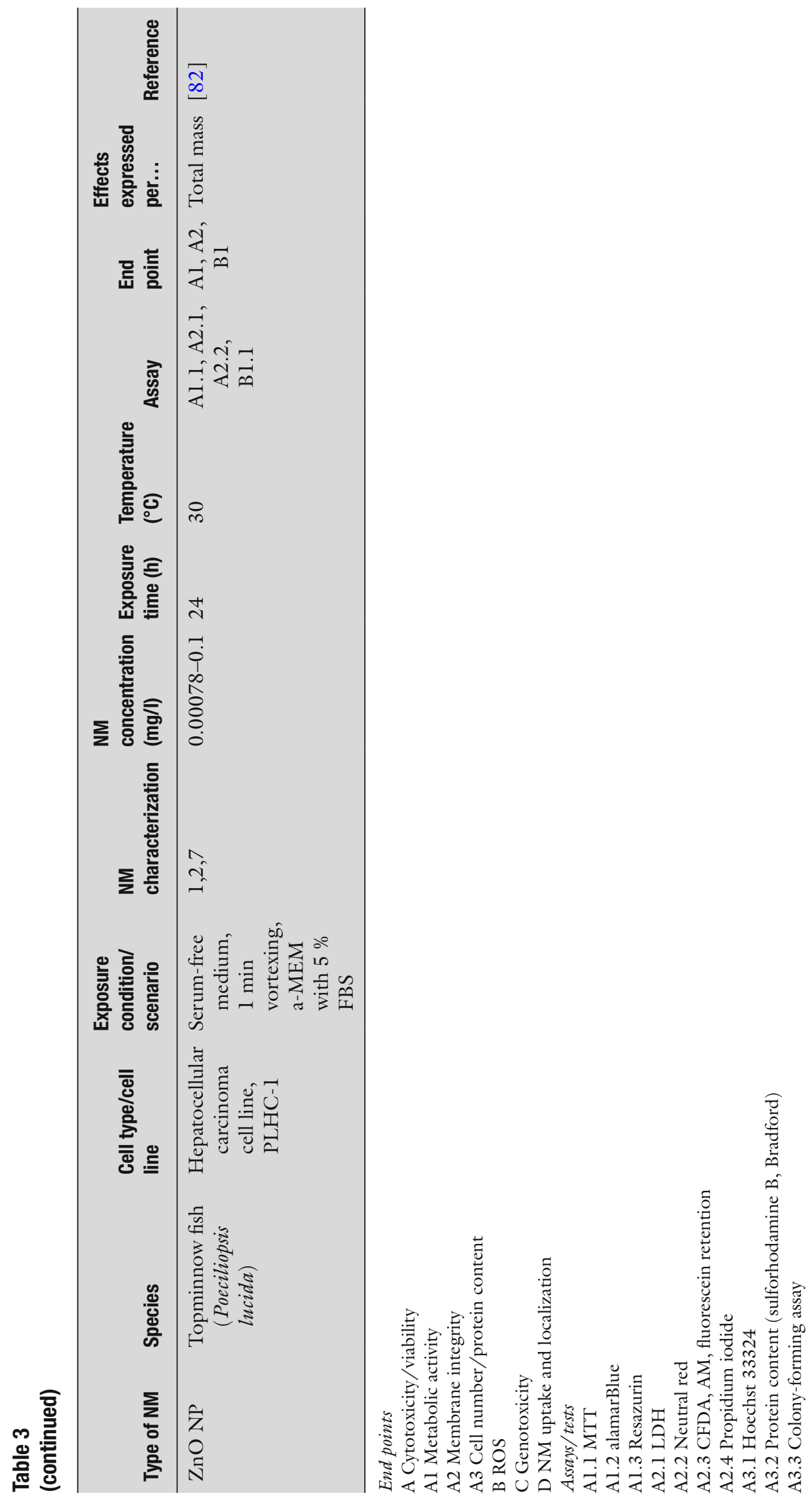




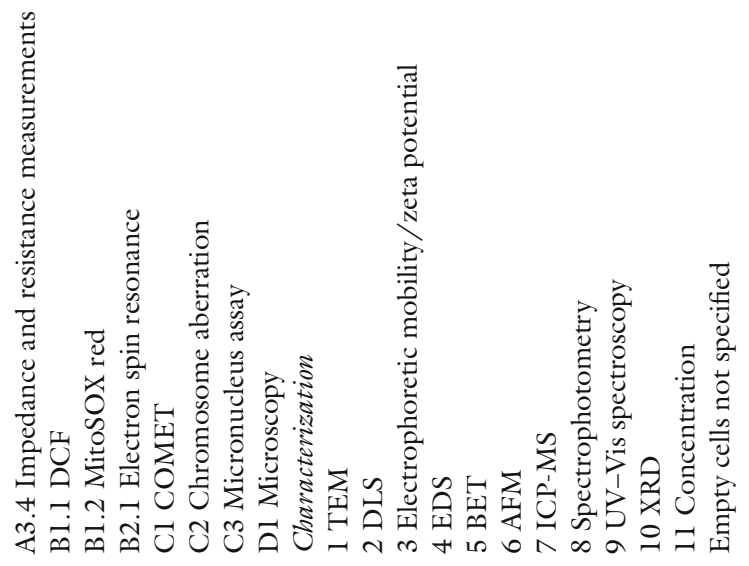




\subsection{Nanomaterial Presentation}

\subsubsection{Generation of NM} Dispersions in fish cell lines. Recovery from NM-induced adverse effects was shown in cell culture and animal tests [23], but has not yet been investigated in ecotoxicological tests. Strikingly, many studies in algae are based on $72 \mathrm{~h}$ exposures, often conducted according to the standard procedures OECD 201 [24], ISO 8692 [25], or DIN 38412-33 [26] (Table 2). Using these standard protocols may imply an easy comparison to data on the toxicity of chemicals. However, these protocols may not be suitable to answer individual research questions on NM toxicity. We further discuss this point in Subheadings 3.4.1 and 3.6.1.

NMs are available as powders or dispersions depending on the production process and posttreatment. Both types need to be dispersed in liquid media for exposure. As described in Fig. 1, dispersions should be generated according to the research approach. The dispersion method can greatly influence the outcome of NM toxicity tests and should thus be carefully chosen [27]. Relevant parameters are dispersion medium chemistry, $\mathrm{pH}$, energy input, time, temperature, and light (see Notes 4-7, 9-12).

Stable, monodisperse NM suspensions with a narrow size distribution are needed to understand the specific effects of a defined size range of the NM under controlled conditions. Dispersion parameters need to be adapted to the respective NM. Depending on the NM surface properties (charged/uncharged, hydrophilic/hydrophobic), which are influenced by surface modifications and the exposure medium ( see Subheading 3.4.1), more or less energy input during the dispersion process is required. Dispersion methods ranging from low energy input, like slow stirring or shaking, to high energy input, like vigorous stirring, shaking, or sonication, have been used (see Tables 2 and 3, see Note 6). The use of surfactants and temperature and/or $\mathrm{pH}$ different from exposure conditions may be required to achieve monodispersed NMs. Filtration or centrifugation may help to narrow the size distribution. Stock dispersions may be generated in a medium different from the exposure medium to ensure optimal dispersion (e.g., ref. 27).

Environmentally relevant or probable conditions may be contrary to the conditions needed to generate stable dispersions. Agglomeration (or possibly aggregation) of the NM may be the consequence (see, e.g., dispersion of Ag NPs in river water [28]). To design environmentally probable conditions, one should determine a relevant type of site in the environment and adapt the dispersion parameters mentioned above accordingly.

Contamination of the NMs by microorganisms or their toxins may affect the test organisms and thus confound toxicity test results [15]. Verifying the sterility of NM for a nonspecialized laboratory is challenging. A simple but superficial approach is to test NM for growth of nonspecialized bacteria in standard media 
3.3.3 Purity

\subsection{Exposure}

3.4.1 Exposure Media (e.g., lysogeny broth (LB)). If available, NM can be tested aerobically and anaerobically for sterility, applying fluid and solid media under long-term cultivation $[15,23]$. The presence of common bacterial toxins (e.g., endotoxins) can be ruled out using available standard kits. Be sure to exclude interferences of the NM with the assay (see Subheading 3.6.1). Sterility of NM powders or suspensions can be achieved by autoclaving [22, 29], $\gamma$-irradiation [30], or possibly filtration. However, one has to verify that these processes do not change NM properties or concentration. We have previously used $\mathrm{X}$-ray photoelectron spectroscopy (XPS) to verify that $\gamma$-irradiation did not change the surface properties of diverse NM [30].

Impurities originating from the production process (or side products formed during preparation of suspensions, e.g., by solvents) may result in measurable toxicity that is independent of actual NM effects and may confound the results [31]. The chemical purity of the NM should thus be determined. If impurities exist, washing steps (if possible) or appropriate controls in the toxicity tests (e.g., using the detected contaminants alone) are recommended.

Depending on the research approach (Fig. 1), exposure conditions need to be adapted either to correspond as closely as possible to environmental conditions or to guarantee maintenance of stable, monodisperse NM suspensions with a narrow size distribution. The following sections describe the influence of different parameters on NM dispersions. They serve as basis to design the exposure conditions according to the desired scenario.

Both algae and fish cells need growth media containing essential nutrients in order to ensure optimal growth and fitness. The constituents of these media will influence NM properties and thus their effects on the test organisms. If dispersion properties are to be controlled, e.g., to generate a stable monodisperse suspension or to minimize dissolution of metallic NM or loss of surface modifiers, the medium may have to be adapted. We recommend to model the speciation of media components including NM (e.g., with Visual MINTEQ, available from KTH, Department of Land and Water Resources Engineering). This helps to understand the fate of NM in the medium and allows optimizing the medium composition if necessary.

Typical liquid minimal algae media contain essential metals (sodium, potassium, calcium, magnesium), chloride, a source of nitrogen (nitrate or ammonium) and inorganic carbon (carbonate), trace metals (copper, zinc, cobalt, manganese, molybdenum, iron, possibly boron), and phosphate. Some algae require an organic carbon source (e.g., citrate), vitamins, or silicon (diatoms). A pH buffer may be necessary and a chelator (e.g., EDTA) to make the metals more bioavailable. Generally, bivalent cations such as 
calcium and magnesium tend to increase the agglomeration of NM; phosphate and carbonate may stabilize NM depending on their surface charge and modification. Ionic strength, $\mathrm{pH}$, and organic compounds will also influence the stability of NM dispersions $\left(\mathrm{TiO}_{2}[30,32], \mathrm{CeO}_{2}\right.$ NPs $[30,33]$, polyethylene glycol (PEG)-coated quantum dots (QDs) (CdSe/ZnS) [34], Ag [28]). Media properties may also change the solubility of NM and possible contaminants which in turn may influence the biological effects. The coating of, e.g., Ag NPs influences their dissolution in different media [35]. Metal-binding compounds such as EDTA or citrate may change the bioavailability of metal ions dissolved from $\mathrm{NM} . \mathrm{NaCl}$ has been shown to enhance dissolution of Ag NPs [36]. Thus, a medium without chloride has been used to expose C. reinhardtii to Ag NPs [28, 37].

As mentioned above, many studies on NM effects on algae have been conducted according to standard test guidelines. This implies the use of standardized culture media. As described in this section, certain components found in standard media influence the dispersibility of NMs or may affect dissolution of NMs. The application of standard protocols should thus be carefully evaluated with respect to the research questions.

For the cultivation of fish cells, different commercially available standard media are in use, e.g., Leibovitz-15 (L-15), minimal essential medium (MEM), or medium 199 (M199). These media contain amino acids, vitamins, inorganic salts, and sugars essential for the growth of heterotrophic cells and differ only slightly in their formulations. Other than mammalian cells, fish cells are usually maintained in $\mathrm{CO}_{2}$-free systems, hence the media does not contain sodium bicarbonate as a buffer, but is buffered by the use of Hank's salts, which buffer at atmospheric $\mathrm{CO}_{2}$ concentrations. Additionally, a higher amino acid content, and complement of galactose is used (e.g., L-15 medium). To allow cell growth and division, the addition of serum is generally needed and the most frequently used is fetal bovine serum (FBS). Serum contains essential growth factors and proteins (e.g., albumin) but may influence NM behavior and hence the toxicity assessment. For example, we and others have found the addition of serum to stabilize NP in the media, hence preventing NP agglomeration [22, 38]. For short-term assays not requiring cell division, serum is not essential and even very simple buffers may be applicable, such as L-15ex [22, 39]. The absence or presence of serum leads to very different particle states and may modulate the particle toxicity [22]. In media without serum, NP may agglomerate due to the high salt content. Depending on tissue of origin, fish cells are capable to grow under hypo- and hyperosmotic conditions (e.g., ref. 11); hence, media with different salt contents can be designed in order to control NM states. The addition of antibiotics to prevent growth of bacteria in the media is common. To date, there are no reports on interference of 
3.4.2 Choice of Light, Temperature, and Agitation antibiotics with NM; however, during exposures, the use of antibiotics is generally not needed and thus should be avoided.

Photoactive NMs such as $\mathrm{TiO}_{2}$ - or $\mathrm{CeO}_{2}$-based NP generate reactive oxygen species (ROS) in the presence of UV and even visible light [40]. They may thus change exposure conditions by catalyzing the oxidation of media components (indirect damage due to change of nutrients). The light-induced generation of ROS may also result into phototoxicity of NM [41]. Photoreduction/oxidation of NM or ions in the medium may change NM dissolution, surface properties, and stability. The choice of light/dark conditions during exposure is therefore an important factor. Light conditions may be influenced locally due to NM shading the cells. This is especially relevant in studies based on photosynthetic organism $[42,43]$ for carbon nanotube-exposed algae, although only extremely high exposure concentrations resulted in this effect.

In previous studies, algae have been exposed under continuous light and light-dark cycles (Table 2). Continuous light produces a more or less homogenous culture and constant conditions, whereas light-dark cycles generate synchronized cultures similar to synchronization by the natural day-night cycle. Fish cells are usually cultivated in the dark and are only exposed to light during work steps performed under the sterile bench (splitting, exposure procedure, toxicity assays). If working with photoactive NM and if desired by the test design, light exposure during these steps can be minimized. On the other hand, it is reasonable to consider exposure under controlled light conditions for cell cultures that represent fish organs naturally exposed to light, such as gills, skin, or eyes $[39,44,45]$.

In a non-agitated exposure system, stable-dispersed NMs move by Brownian motion which is dependent on, i.e., the temperature of the system. Consequently, the temperature influences NM behavior (e.g., speed, agglomeration, and contact with surfaces) and possibly interaction with organisms. Fish cells are typically cultured at $15-34{ }^{\circ} \mathrm{C}$, depending on the species from which fish cells are derived (see Subheading 3.1.2), while temperatures reported for algae cultures range from 15 to $26^{\circ} \mathrm{C}$.

\subsubsection{Agitation}

\subsection{Bioavailability}

Agitation (e.g., stirring, shaking, flowing) influences the stability of the NM dispersion and the way and frequency of organism-NM encounter. Fish cells grown in monolayers are cultivated in nonagitated systems; however, suspension cultures may need agitation. Algae are typically agitated by $\mathrm{CO}_{2}$ flow-through, stirring, or shaking.

To understand toxic effects of NM, it is important to characterize the NM in the exposure system with regard to size and charge as detailed as possible (Fig. 1). Furthermore, the distribution of 


\subsubsection{Characterization} of NM in Exposure Media

Size the NM in the exposure system in the different compartments, i.e., the mass balance including possible dissolution, is an essential information for the interpretation of results. The NM characterization techniques need to be applicable to relevant NM concentrations. An overview of characterization methods is provided below. For a more detailed review, please refer to the literature $[12,46]$.

The size, among other properties, will determine the behavior of NM in suspension and thus its interaction with organisms. The most commonly used techniques for size characterization in NM toxicology are scanning electron microscopy (SEM) or transmission electron microscopy (TEM) or dynamic light scattering (DLS). The use of nanoparticle tracking analysis (NTA) is increasing. While EM provides images of typically dry material in high vacuum, DLS and NTA measure the hydrodynamic diameter in liquids, and calculations are based on spherical representations of the NM. Details and limitations of the methods can be found in specific literature (see Notes 2, 3, and 13).

In general, designing environmentally relevant or probable exposure scenarios may be contrary to the optimal sample properties for these techniques. For example, natural additives, like humic or fulvic acid or dissolved organic matter (DOC), can influence the measurements. All three methods have their limitations regarding the detectable NM concentration range. As environmentally relevant concentrations may be very low (e.g., up to $\mu \mathrm{g} / \mathrm{L}$ instead of mg to $g / L)$, characterizing NM size at these concentrations may be impossible or unfeasible with these methods to date. Field-flow fractionation (FFF) coupled to elemental analysis is applicable to very low NM concentrations but entails the removal of the NM from the exposure medium. The same holds true for the detection of single particles by inductively coupled plasma mass spectrometry (ICP-MS). The surface plasmon resonance (SPR) of metallic NP, especially silver and gold, can be measured by UV-Vis spectrophotometry and provide size information as the SPR peak wavelength depends on the NP size. DLS is not applicable to very polydisperse or unstable suspensions which might, however, represent the NP state in the environment. Large and/or sticky NM/agglomerates that adhere to the surfaces of the NTA sample compartment may also make reliable measurements challenging. Agglomerated NM are a common issue depending on the culture media and dispersion method (see Subheadings 3.6.1 and 3.6.2).

In summary, the more monodisperse the sample is and within the optimal concentration range of the methods, the more reproducible and meaningful are the results. We usually employ DLS, NTA, and EM in combination to profit from the complementary information gathered. 
Zeta Potential and Electrophoretic Mobility

3.5.2 Mass Balance and Bioaccumulation of NM
The zeta potential of a particle system is a measure for its surface charge and is indicative of particle stability and interactions with components of the suspension (molecules, other particles, surfaces) and test organisms. It can be derived mathematically from the electrophoretic mobility of particles within an electric field. Most publications list the derived zeta potential, but providing electrophoretic mobility data helps to compare results independent of the assumptions made when calculating zeta potential. Like size measurements in liquids, the optimal conditions for electrophoretic mobility analysis may not be fulfilled by environmentally relevant NM dispersions. The electrophoretic mobility/zeta potential strongly depends on the $\mathrm{pH}$ of a solution; hence, information on the $\mathrm{pH}$ value of a solution/medium is required. Shifts in $\mathrm{pH}$ (e.g., by oxidation processes or due to cell metabolism) during an exposure may lead to the presence of different particle states in an exposure period; usually this is prevented by using a buffer system with suitable capacity.

Dispersed NM will partition to different parts of the exposure system depending on its material properties, exposure conditions (solution chemistry, agitation, temperature, illumination), material properties and surface area of the containers used, and the properties and number of the test organisms. Possible redistribution processes from the dispersion of both NM and ions or surface modifiers dissolved from the NM are:

1. Sorption to abiotic and biotic surfaces

2. Uptake by test organisms

3. Sedimentation.

The amount of NM in these different compartments should be quantified to understand the distribution of NM during the exposure. Quantifying NM adsorbed to abiotic surfaces may be difficult to determine but can be deduced from the initial total concentration of NM and the amount present on/in the organisms, in suspension, and possibly in the sediment.

The possible dissolution, coating or surface modification (engineered or by media components), and speciation of a NM change the bioavailability of its components and may influence its effects on test organisms. Thus, these properties should be analyzed under exposure conditions to understand which factor actually elicited measured effects.

The chemical characterization of nonorganic carbon-based NM is typically done via ICP-MS, ICP-AES (atomic emission spectroscopy), or ICP-OES (optical emission spectrometry) following adapted acidic digestion of the NM. When working in culture media, be sure to use matrix-adapted calibration curves. Organic carbon-based NM can be assessed via, e.g., OCEC (organic carbon-elemental carbon) analyzers based on infrared spectrometry. 
3.5.3 Intracellular Localization of NM

\subsection{Effects}

Dissolved ions may be separated by, e.g., ultrafiltration, diffusive gradients in thin films (DGT) devices, or dialysis prior to chemical analysis or detected by ion selective electrodes. Surface composition may be determined by XPS.

Metal analysis (e.g., by ICP-MS) of entire cells (or possibly subcellular fractions) following acidic digestion informs about bioaccumulation of the NM within cells but does not differentiate between dissolved and particulate material. At the moment, determining intracellular mass balance and speciation is difficult or impossible, depending on the NM and test organism. One reported approach was based on radioactive NPs to facilitate detection and assess bioavailability of $\mathrm{ZnO} \mathrm{NP}$ in algae [47]. To differentiate between $\mathrm{Ag} \mathrm{NP}$ and $\mathrm{Ag}^{+}$adsorbed to the surface of cells and intracellular silver, one study used several wash steps including cystein to bind $\mathrm{Ag}^{+}[37]$.

For the interpretation of toxicity test results, information on the localization of NM in or on cells is helpful. The method for detection of NM associated with and in cells depends on the NM and the organism. A combination of different methods should be used to account for the limitations of individual techniques. Optically dense NMs can be visualized by light microscopy (LM); however, it does not provide proof of the chemical identity of the detected particles. As fish cells are transparent, this type of visualization is feasible. LM can be unusable for algae with a cell wall and/or an optically dense cytosol. Electron microscopy of fixed and dried samples provides high-resolution images and can be coupled to, e.g., energy-dispersive X-ray spectroscopy (EDX) to give evidence of the NM chemistry. Preparation artifacts may distort the localization of NMs in the sample. Alternatives such as environmental SEM/TEM which do not require vacuum in the specimen chamber and thus do not require a dry sample are currently being refined. Fluorescence or preferably confocal laser scanning microscopy (CLSM) are valuable to visualize fluorescent NMs [48]. Depending on the fluorescence wavelength emitted by the NMs, algal autofluorescence may interfere with NM detection. Metal-containing NMs exhibit size-dependent surface plasmon resonance when interacting with light and can thus be visualized by CLSM in reflection mode [49]. For ions released from metallic NM, metal specific fluorescent probes may be used to detect dissolved fractions of NM within cells. This approach is limited by the detection limit of the probes and cross-reactivity with other metals. One possibly feasible approach is coupling CLSM with Raman spectroscopy to resolve subcellular chemistry in the nanometer range.

Algae and fish cells can be explored for NM effects in many different ways. One common approach is indicator dyes that can be assessed either by fluorescence, luminescence, or by absorbance; 
a large variety of such indicator dyes is commercially available. Among them are indicator dyes to assess viability, ATP content, or formation of ROS (Fig. 1). Taking some limitations due to autofluorescent biomolecules, such as chlorophylls, into account, these indicator dyes can generally be applied to both algal and fish cells ( see Tables 1 and 2 but as well as $[13,14]$ as examples for effect assessment in fish cells and $[50,51]$ for examples of effect assessment in unicellular algae). Also fluorescence-based are methods to quantify photosynthetic activity of NM-exposed algae, such as via pulse-amplitude modulated (PAM) fluorometry. PAM provides a measure of the relative activity of photosystem II reaction centers at a given time and information on which part of the electron transport chain is affected in response to a stressor. In principle, one can make use of the variety of effect measurements established also for exposure of cells to chemicals, including genotoxicity, gene and protein expression, and impact on enzyme activity ( see Notes 14-18 for critical points in choosing end points).

The key to successfully applying effect-focused assays is to include appropriate controls to take potential interferences by NMs into account. For example, carbon-based NMs have a high sorption capacity also for hydrophobic fluorescence indicator dyes, which may render some of these dyes impossible to use to measure NM cellular effects [52]. Another important aspect is how to express the effect assessment results in terms of exposure or dose. These two aspects, interferences/controls and dose metrics, are briefly discussed below.

3.6.1 Potential Interferences and Appropriate Controls
NMs have a high surface-to-volume ratio and possess specific physicochemical properties which make them prone to interfere with certain types of toxicity tests [30]. Possible interferences that need to be ruled out by appropriate cell-free controls are listed in Table 1 (also see Note 8). In certain cases it may be difficult to distinguish between the different types of interferences. Different surface modifications of NM may induce different interferences. Media components may also interact with the reaction substrate, product, or enzyme. The medium should thus be tested in the same way as NM dispersions.

With regard to the NMs, two types of controls should be considered: reference NMs to rank the test results and make them better comparable to other studies and positive controls to verify the functionality of the toxicity test. A repository of representative NMs has recently been established by the Institute for Health and Consumer Protection (IHCP) of the European Commission Joint Research Centre (EC JRC) [53]. However, round robin tests based on these materials have not yet been published. To distinguish between the effects of ions and particulate material of soluble NMs, appropriate characterization methods help to know the 
3.6.2 Dose Metrics extent of ion dissolution or impurities from the production process. Additionally, controls with ion chelators and metal salts are recommended. Surface modifications may also induce effects independent of the NMs. It may thus be reasonable to test surface modifiers independent of the NM.

Dose metrics is a widely debated issue in nanotoxicology. Possible bases to express measured effects are the total mass, the surface area of the dry material, or the number concentration. Furthermore, these can be expressed per cell surface, cell volume, cell number, or total exposure volume. The most common choice is total mass per total exposure volume, mostly given in mass NM/volume medium (see Tables 2 and 3 ). The total mass is the easiest to measure but does not account for size distribution. NM surface area and number have to be derived from other information (most often size distribution by intensity) which may be biased toward smaller or larger particles and also do not account for size distribution. Additionally, in case of NM agglomeration (or possibly aggregation) in the test media, both size and free surface area may change. Certain assumptions such as uniform shape have to be made. Cell number and exposure volume are easy to determine, while cell surface and volume have to be derived also in making certain assumptions. In summary, none of the combinations is a perfect solution. Using total mass per exposure volume and providing a thorough NM dispersion characterization and detailed description of exposure conditions is one approach to increase comparability of reported results because it also allows for recalculating different dose metrics. For soluble NMs it is recommended to use the dissolved fraction as well as total concentration as basis to compare toxicity of different treatments to see whether free ions can explain the measured toxicity and whether it is identical or different for different forms of the same material.

\section{Notes}

1. Laboratory safety: Be sure to protect yourself and your colleagues from exposure to NM. If possible, dedicate a specific area in the laboratory to handling NM. In particular, a dedicated hood should be used for powdered material. We additionally keep track of the NM handled in the nano-laboratory and the involved persons. Handling NM waste is an important issue and should be discussed with the personnel responsible for chemical waste.

2. Containers: Consider choosing your dispersion and exposure containers depending on the tested NM, e.g., using plastics to minimize metal adsorption during exposure. 
3. Glass ware: Soak in diluted $\mathrm{HNO}_{3}$ to minimize adsorption of metals to the surface during experiments; muffle in case you need to determine organic carbon.

4. Sonication: Be sure to use indirect sonication to avoid metal contamination by direct sonication.

5. NM may have to be cleaned every time before use (e.g., ref. 42).

6. NPs may change agglomeration state in the presence of cells [68].

7. Properties of purchased NM may vary between different lots. This may be a cause of variable responses in the toxicity tests.

8. Test results may prove to be irreproducible in independent experiments or show high standard deviations (e.g., ref. 56), which requires troubleshooting. One cause of this variability may be differences in NM dispersions or nonintuitive factors such as frequency of opening and closing of incubators during growth and exposure.

9. Due to the variation in NM preparation and of exposure conditions in available reports, results (see Table 1) may differ from reported values even if the same NM and same organism was used.

10. DLS: Discard all DLS data not meeting software quality criteria.

11. NTA: Carefully adjust the data processing settings to the sample analyzed.

12. The methods for NM characterization that are currently available are limited regarding very low (but likely environmentally relevant) concentrations of NM.

13. Most of the toxicity end points reported in the literature to date are descriptors of the general state of cell cultures (such as growth rate, membrane integrity, photosynthetic activity).

14. Most methods were adopted from the testing of chemicals.

15. Direct interaction with intra- and extracellular molecules (e.g., DNA, specific enzymes, and extracellular polymeric substances) has not been studied.

16. The influence of NMs on the cell cycle and biochemical pathways is still unexplored.

17. We are far from understanding the mechanisms of interaction between the considered biological models and NM.

18. To minimize interference with subsequent measurements, cells should be washed, taking into account the chemistry and charge of extracellular substances and of the NM (e.g., slightly acidic buffer to neutralize extracellular negative charges and thus weaken NM-cell interaction). 


\section{References}

1. European Commission (2012-01-22) http:// europa.eu/rapid/pressReleasesAction.do?refe rence $=\mathrm{IP} / 11 / 1202 \&$ format $=$ HTML\&aged $=$ 0 \&language $=\mathrm{EN} \&$ guiLanguage $=\mathrm{en}$

2. Jiang J, Oberdörster G, Biswas P (2009) Characterization of size, surface charge, and agglomeration state of nanoparticle dispersions for toxicological studies. J Nanoparticle Res 11:77-89

3. Lewis LA, McCourt RM (2004) Green algae and the origin of land plants. Am J Bot 91: $1535-1556$

4. Weyers A, Sokull-Klüttgen B, BaraibarFentanes J, Vollmer G (2000) Acute toxicity data: a comprehensive comparison of results of fish, daphnia, and algae tests with new substances notified in the European Union. Environ Toxicol Chem 19:1931-1933

5. Lee RE (2008) Phycology (4 ed.) Cambridge University Press, Cambridge, UK.

6. Kneip C, Voss C, Lockhart PJ, Maier UG (2008) The cyanobacterial endosymbiont of the unicellular algae Rhopalodia gibba shows reductive genome evolution. BMC Evol Biol 8:30

7. Bols NC, Dayeh VR, Lee LEJ, Schirmer K (2005) Use of fish cell lines in the toxicology and ecotoxicology of fish. In: Mommsen TP, Moon TW (eds) Biochemistry and molecular biology of fishes. Elsevier Science, Amsterdam

8. Schirmer K (2006) Proposal to improve vertebrate cell cultures to establish them as substitutes for the regulatory testing of chemicals and effluents using fish. Toxicology 224: 163-183

9. Surek B (2008) Meeting report: algal culture collections 2008. An international meeting at the culture collection of algae and protozoa (CCAP), Dunstaffnage Marine Laboratory, Dunbeg, Oban, UK, June 8-11, 2008, Protist 159:509-517.

10. Gachon CM, Day JG, Campbell CN, Proschold T, Saxon RJ, Kupper FC (2007) The culture collection of algae and protozoa (CCAP): a biological resource for protistan genomics. Gene 406:51-57

11. Lee LE, Daveh VR, Schirmer K, Bols NC (2009) Applications and potential uses of fish gill cell lines: examples with RTgill-Wl. In Vitro Cell Dev Biol Anim 45:127-134

12. Meissner T, Kuhnel D, Busch W, Oswald S, Richter V, Michaelis A, Schirmer K, Potthoff A (2010) Physical-chemical characterization of tungsten carbide nanoparticles as a basis for toxicological investigations. Nanotoxicology 4:196-206

13. Dayeh VR, Schirmer K, Lee LEJ, Bols NC (2005) Rainbow trout gill cell line microplate cytotoxicity test. In: Blaise C, Férard JF (eds)
Small-scale freshwater environment toxicity test methods. Kluwer, Norwell, MA, pp 473-503

14. Dayeh VR, Bols NC, Schirmer K, Lee LE (2003) The use of fish-derived cell lines for investigation of environmental contaminants. Curr Protoc Toxicol Chapter 1, Unitl 5.

15. Losic D, Rosengarten G, Mitchell JG, Voelcker NH (2006) Pore architecture of diatom frustules: potential nanostructured membranes for molecular and particle separations. J Nanosci Nanotechnol 6:982-989

16. Naustvoll L-J (1998) Growth and grazing by the thecate heterotrophic dinoflagellate Diplopsalis lenticula (Diplopsalidaceae, Dinophyceae). Phycologia 37:1-9

17. Gottschalk F, Sonderer T, Scholz RW, Nowack B (2009) Modeled environmental concentrations of engineered nanomaterials $\left(\mathrm{TiO}_{2}\right.$, $\mathrm{ZnO}, \mathrm{Ag}, \mathrm{CNT}$, fullerenes) for different regions. Environ Sci Technol 43:9216-9222

18. Luoma SN (2008) Silver nanotechnologies and the environment: old problems or new challenges? In: Project on emerging nanotechnologies report, PEN 15. Woodrow Wilson Centre, Washington, DC, pp 1-67

19. Tiede K, Hassellöv M, Breitbarth E, Chaudhry Q, Boxall ABA (2009) Considerations for environmental fate and ecotoxicity testing to support environmental risk assessments for engineered nanoparticles. J Chromatogr A 1216:503-509

20. Velzeboer I, Hendriks AJ, Ragas AMJ, van de Meent D (2008) Nanomaterials in the environment aquatic ecotoxicity tests of some nanomaterials. Environ Toxicol Chem 27: 1942-1947

21. Bouldin JL, Ingle TM, Sengupta A, Alexander R, Hannigan RE, Buchanan RA (2008) Aqueous toxicity and food chain transfer of quantum $\operatorname{dots}^{\mathrm{TM}}$ in freshwater algae and Ceriodaphnia dubia. Environ Toxicol Chem 27:1958-1963

22. Kühnel D, Busch W, Meißner T, Springer A, Potthoff A, Richter V, Gelinsky M, Schirmer K (2009) Agglomeration of tungsten carbide nanoparticles in exposure medium does not prevent uptake and toxicity toward a rainbow trout gill cell line. Aquat Toxicol 93:91-99

23. Landsiedel R, Ma-Hock L, Kroll A, Hahn D, Schnekenburger J, Wiench K, Wohlleben W (2010) Testing metal-oxide nanomaterials for human safety. Adv Mater 22:2601-2627

24. OECD (2011),Test No. 201: Freshwater Alga and Cyanobacteria, Growth Inhibition Test, OECD Guidelines for the Testing of Chemicals, Section 2, OECD Publishing. doi: $10.1787 / 9789264069923$-en 
25. ISO (2012) Water quality-Fresh water algal growth inhibition test with unicellular green algae (ISO 8692:2012). International Organization for Standardization.

26. German standard methods for the examination of water, waste water and sludge; bio-assays (group L); determining the tolerance of green algae to the toxicity of waste water (Scenedesmus chlorophyll fluorescence test) by way of dilution series (L 33), (DIN 38412-33:1991-03)

27. Hund-Rinke K, Schlich K, Wenzel A (2010) $\mathrm{TiO} 2$ nanoparticles - relationship between dispersion preparation method and ecotoxicity in the algal growth test. Umweltwissenschaften und Schadstoff-Forschung 22:517-528

28. Piccapietra F, Sigg L, Behra R (2011) Colloidal stability of carbonate-coated silver nanoparticles in synthetic and natural freshwater. Environ Sci Technol 46:818-825

29. Hildebrand H, Kühnel D, Potthoff A, Mackenzie K, Springer A, Schirmer K (2009) Evaluating the cytotoxicity of palladium/magnetite nano-catalysts intended for wastewater treatment. Environ Pollut 158:65-73

30. Schulze C, Kroll A, Lehr CM, Schäfer UF, Becker K, Schnekenburger J, Schulze Isfort C, Landsiedel R, Wohleben W (2008) Not ready to use-overcoming pitfalls when dispersing nanoparticles in physiological media. Nanotoxicology 2:51-61

31. Hull MS, Kennedy AJ, Steevens JA, Bednar AJ, Weiss JCA, Vikesland PJ (2009) Release of metal impurities from carbon nanomaterials influences aquatic toxicity. Environ Sci Technol 43:4169-4174

32. Sharma V, Shukla RK, Saxena N, Parmar D, Das M, Dhawan A (2009) DNA damaging potential of zinc oxide nanoparticles in human epidermal cells. Toxicol Lett 185:211-218

33. Van Hoecke K, De Schamphelaere KAC, Van der Meeren P, Smagghe G, Janssen CR (2011) Aggregation and ecotoxicity of $\mathrm{CeO}_{2}$ nanoparticles in synthetic and natural waters with variable $\mathrm{pH}$, organic matter concentration and ionic strength. Environ Pollut 159: 970-976

34. Slaveykova VI, Startchev K (2009) Effect of natural organic matter and green microalga on carboxyl-polyethylene glycol coated CdSe/ $\mathrm{ZnS}$ quantum dots stability and transformations under freshwater conditions. Environ Pollut 157:3445-3450

35. Odzak N, Behra R, Sigg L (2013) Dissolution of metal and metal oxide nanoparticles in aqueous media. Manuscript in preparation.

36. Kent RD, Vikesland PJ (2012) Controlled evaluation of silver nanoparticle dissolution using atomic force microscopy. Environ Sci Technol 46(13):6977-6984
37. Navarro E, Piccapietra F, Wagner B, Marconi F, Kaegi R, Odzak N, Sigg L, Behra R (2008) Toxicity of silver nanoparticles to Chlamydomonas reinhardtii. Environ Sci Technol 42:8959-8964

38. Deguchi S, Yamazaki T, Mukai SA, Usami R, Horikoshi K (2007) Stabilization of C(60) nanoparticles by protein adsorption and its implications for toxicity studies. Chem Res Toxicol 20:854-858

39. Schirmer K, Chan AG, Greenberg BM, Dixon DG, Bols NC (1997) Methodology for demonstrating and measuring the photocytotoxicity of fluoranthene to fish cells in culture. Toxicol In Vitro 11:107-119

40. Rogers NJ, Franklin NM, Apte SC, Batley GE, Angel BM, Lead JR, Baalousha M (2010) Physico-chemical behaviour and algal toxicity of nanoparticulate $\mathrm{CeO}_{2}$ in freshwater. Environ Chem 7:50-60

41. Ma H, Kabengi NJ, Bertsch PM, Unrine JM, Glenn TC, Williams PL (2011) Comparative phototoxicity of nanoparticulate and bulk $\mathrm{ZnO}$ to a free-living nematode Caenorhabditis elegans: the importance of illumination mode and primary particle size. Environ Pollut 159:1473-1480

42. Hund-Rinke K, Simon M (2006) Ecotoxic Effect of Photocatalytic Active Nanoparticles (TiO2) on Algae and Daphnids. Environ Sci Pollut Res 13:225-232

43. Schwab F, Bucheli TD, Lukhele LP, Magrez A, Nowack B, Sigg L, Knauer K (2011) Are Carbon Nanotube Effects on Green Algae Caused by Shading and Agglomeration? Environ Sci Technol 45:6136-6144

44. Laycock NL, Schirmer K, Bols NC, Sivak JG (2000) Optical properties of rainbow trout lenses after in vitro exposure to polycyclic aromatic hydrocarbons in the presence or absence of ultraviolet radiation. Exp Eye Res 70: 205-214

45. Schirmer K, Chan AG, Greenberg BM, Dixon DG, Bols NC (1998) Ability of 16 priority PAHs to be photocytotoxic to a cell line from the rainbow trout gill. Toxicology 127:143-155

46. Hassellöv M, Readman J, Ranville J, Tiede K (2008) Nanoparticle analysis and characterization methodologies in environmental risk assessment of engineered nanoparticles. Ecotoxicology 17:344-361

47. Peng X, Palma S, Fisher NS, Wong SS (2011) Effect of morphology of $\mathrm{ZnO}$ nanostructures on their toxicity to marine algae. Aquatic Toxicology 102:186-196

48. Xu M, Deng G, Liu S, Chen S, Cui D, Yang L, Wang Q (2010) Free cadmium ions released from CdTe-based nanoparticles and their cytotoxicity on Phaeodactylum tricornutum. Metallomics 2:469-473 
49. Tsai S-W, Chen Y-Y, Liaw J-W (2008) Compound Cellular Imaging of Laser Scanning Confocal Microscopy by Using Gold Nanoparticles and Dyes. Sensors 8:2306-2316

50. Nestler H, Groh KJ, Schonenberger R, Behra R, Schirmer K, Eggen RI, Suter MJ (2012) Multiple-endpoint assay provides a detailed mechanistic view of responses to herbicide exposure in Chlamydomonas reinhardtii. Aquat Toxicol 110-111:214-224

51. Szivák I, Behra R, Sigg L (2009) Metalinduced reactive oxygen species production in chlamydomonas reinhardtii (Chlorophyceae) 1 . J Phycol 45:427-435

52. Kroll A, Pillukat MH, Hahn D, Schnekenburger $\mathrm{J}$ (2012) Interference of engineered nanoparticles with in vitro toxicity assays, Arch Tox 86(7):1123-1136

53. European Commission Joint Research Centre. (2012-01-22). http://ihcp.jrc.ec.europa.eu/ our_activities/nanotechnology/ nanomaterials-repository

54. Miao A-J, Schwehr KA, Xu C, Zhang S-J, Luo Z, Quigg A, Santschi PH (2009) The algal toxicity of silver engineered nanoparticles and detoxification by exopolymeric substances. Environ Pollut 157:3034-3041

55. Renault S, Baudrimont M, Mesmer-Dudons N, Gonzalez P, Mornet S, Brisson A (2008) Impacts of gold nanoparticle exposure on two freshwater species: a phytoplanktonic alga (Scenedesmus subspicatus) and a benthic bivalve (Corbicula fluminea). Gold Bull 41:116-126

56. Baun A, Sørensen SN, Rasmussen RF, Hartmann NB, Koch CB (2008) Toxicity and bioaccumulation of xenobiotic organic compounds in the presence of aqueous suspensions of aggregates of nano-C60. Aquat Toxicol 86: 379-387

57. Rodea-Palomares I, Boltes K, Fernández-Piñas F, Leganés F, García-Calvo E, Santiago J, Rosal R (2011) Physicochemical characterization and ecotoxicological assessment of $\mathrm{CeO}_{2}$ nanoparticles using two aquatic microorganisms. Toxicol Sci 119:135-145

58. Van Hoecke K, Quik JTK, Mankiewicz-Boczek J, Schamphelaere KACD, Elsaesser A, Meeren PVD, Barnes C, McKerr G, Howard CV, Meent DVD, Rydzyński K, Dawson KA, Salvati A, Lesniak A, Lynch I, Silversmit G, Samber BRD, Vincze L, Janssen CR (2009) Fate and effects of $\mathrm{CeO}_{2}$ nanoparticles in aquatic ecotoxicity tests. Environ Sci Technol 43:4537-4546

59. Blaise C, Gagné F, Férard JF, Eullaffroy P (2008) Ecotoxicity of selected nano-materials to aquatic organisms. Environ Toxicol 23:591-598

60. Aruoja V, Dubourguier H-C, Kasemets K, Kahru A (2009) Toxicity of nanoparticles of $\mathrm{CuO}, \mathrm{ZnO}$ and $\mathrm{TiO}_{2}$ to microalgae
Pseudokirchneriella subcapitata. Sci Total Environ 407:1461-1468

61. Saison C, Perreault F, Daigle J-C, Fortin C, Claverie J, Morin M, Popovic R (2010) Effect of core-shell copper oxide nanoparticles on cell culture morphology and photosynthesis (photosystem II energy distribution) in the green alga, Chlamydomonas reinhardtii. Aquat Toxicol 96:109-114

62. Li M, Czymmek KJ, Huang CP (2011) Responses of Ceriodaphnia dubia to $\mathrm{TiO}_{2}$ and $\mathrm{Al}_{2} \mathrm{O}_{3}$ nanoparticles: a dynamic nano-toxicity assessment of energy budget distribution. J Hazardous Mater 187:502-508

63. Wei L, Thakkar M, Chen Y, Ntim SA, Mitra S, Zhang X (2010) Cytotoxicity effects of water dispersible oxidized multiwalled carbon nanotubes on marine alga, Dunaliella tertiolecta. Aquat Toxicol 100:194-201

64. Naha PC, Bhattacharya K, Tenuta T, Dawson KA, Lynch I, Gracia A, Lyng FM, Byrne HJ (2010) Intracellular localisation, geno- and cytotoxic response of poly $\mathrm{N}$-isopropylacrylamide (PNIPAM) nanoparticles to human keratinocyte (HaCaT) and colon cells (SW 480). Toxicol Lett 198:134-143

65. Wang J, Zhang X, Chen Y, Sommerfeld M, Hu Q (2008) Toxicity assessment of manufactured nanomaterials using the unicellular green alga Chlamydomonas reinhardtii. Chemosphere 73:1121-1128

66. Fujiwara K, Suematsu H, Kiyomiya E, Aoki M, Sato M, Moritoki N (2008) Size-dependent toxicity of silica nano-particles to Chlorella kessleri. J Environ Sci Health Part A 43: 1167-1173

67. Van Hoecke K, De Schamphelaere KAC, Van der Meeren P, Lcucas S, Janssen CR (2008) Ecotoxicity of silica nanoparticles to the green alga pseudokirchneriella subcapitata: importance of surface area. Environ Toxicol Chem 27:1948-1957

68. Cherchi C, Chernenko T, Diem M, Gu AZ (2011) Impact of nano titanium dioxide exposure on cellular structure of Anabaena variabilis and evidence of internalization. Environ Toxicol Chem 30:861-869

69. Miller RJ, Lenihan HS, Muller EB, Tseng N, Hanna SK, Keller AA (2010) Impacts of metal oxide nanoparticles on marine phytoplankton. Environ Sci Technol 44:7329-7334

70. Hall S, Bradley T, Moore JT, Kuykindall T, Minella L (2009) Acute and chronic toxicity of nano-scale $\mathrm{TiO}_{2}$ particles to freshwater fish, cladocerans, and green algae, and effects of organic and inorganic substrate on $\mathrm{TiO}_{2}$ toxicity. Nanotoxicology 3:91-97

71. Rodríguez-González V, Alfaro SO, TorresMartínez LM, Cho S-H, Lee S-W (2010) Silver- $\mathrm{TiO}_{2}$ nanocomposites: synthesis and 
harmful algae bloom UV-photoelimination. Appl Catal B: Environ 98:229-234

72. Warheit DB, Hoke RA, Finlay C, Donner EM, Reed KL, Sayes CM (2007) Development of a base set of toxicity tests using ultrafine $\mathrm{TiO}_{2}$ particles as a component of nanoparticle risk management. Toxicol Lett 171:99-110

73. Franklin NM, Rogers NJ, Apte SC, Batley GE, Gadd GE, Casey PS (2007) Comparative toxicity of nanoparticulate $\mathrm{ZnO}$, Bulk $\mathrm{ZnO}$, and $\mathrm{ZnCl}_{2}$ to a freshwater microalga (Pseudokirchneriella subcapitata): the importance of particle solubility. Environ Sci Technol 41:8484-8490

74. Miao A-J, Zhang X-Y, Luo Z, Chen C-S, Chin W-C, Santschi PH, Quigg A (2010) Zinc oxide-engineered nanoparticles: dissolution and toxicity to marine phytoplankton. Environ Toxicol Chem 29:2814-2822

75. Wise JP Sr, Goodale BC, Wise SS, Craig GA, Pongan AF, Walter RB, Thompson WD, Ng AK, Aboueissa AM, Mitani H, Spalding MJ, Mason MD (2010) Silver nanospheres are cytotoxic and genotoxic to fish cells. Aquat Toxicol 97:34-41

76. Hondroulis E, Liu C, Li CZ (2010) Whole cell based electrical impedance sensing approach for a rapid nanotoxicity assay. Nanotechnology 21:315103

77. George S, Lin S, Ji Z, Thomas CR, Li L, Mecklenburg M, Meng H, Wang X, Zhang H, Xia T, Hohman JN, Lin S, Zink JI, Weiss PS,
Nel AE (2012) Surface defects on plate-shaped silver nanoparticles contribute to its hazard potential in a fish gill cell line and Zebrafish embryos. ACS Nano 6(5):3745-3759

78. Van Hoecke K, De Schamphelaere KA, Ali Z, Zhang F, Elsaesser A, Rivera-Gil P, Parak WJ, Smagghe G, Howard CV, Janssen CR (2013) Ecotoxicity and uptake of polymer coated gold nanoparticles. Nanotoxicology 7(1): $37-47$

79. Naha PC, Casey A, Tenuta T, Lynch I, Dawson KA, Byrne HJ, Davoren M (2009) Preparation, characterization of NIPAM and NIPAM/ BAM copolymer nanoparticles and their acute toxicity testing using an aquatic test battery. Aquat Toxicol 92:146-154

80. Reeves JF, Davies SJ, Dodd NJ, Jha AN (2008) Hydroxyl radicals $(\mathrm{OH})$ are associated with titanium dioxide $(\mathrm{TiO}(2))$ nanoparticleinduced cytotoxicity and oxidative DNA damage in fish cells. Mutat Res 640:113-122

81. Vevers WF, Jha AN (2008) Genotoxic and cytotoxic potential of titanium dioxide $\left(\mathrm{TiO}_{2}\right)$ nanoparticles on fish cells in vitro. Ecotoxicology 17:410-420

82. Fernández-Cruz ML, Lammel L, Connolly M, Conde E, Barrado AI, Derick S, Perez Y, Fernandez M, Furger C, Navas JM (2012) Comparative cytotoxicity induced by bulk and nanoparticulated $\mathrm{ZnO}$ in the fish and human hepatoma cell lines PLHC-1 and Hep G2 Nanotoxicology early online 1-18. 